\title{
Exploring discourse surrounding therapeutic enhancement of veterans and soldiers with injuries
}

\author{
Gregor Wolbring $^{\mathrm{a}, *}$, Angelica Martin ${ }^{\mathrm{b}}$, Jeremy Tynedal ${ }^{\mathrm{c}}$, Natalie Ball ${ }^{\mathrm{b}}$ and Sophya Yumakulov ${ }^{\mathrm{b}}$ \\ ${ }^{\mathrm{a}}$ Department of Community Health Sciences, Program of Community Rehabilitation and Disability Studies, \\ University of Calgary, Calgary, Canada \\ ${ }^{\mathrm{b}}$ Faculty of Medicine, University of Calgary, Calgary, Canada \\ ${ }^{\mathrm{c}}$ Faculty of Kinesiology, University of Calgary, Calgary, Canada
}

Received 15 November 2012

Accepted 13 May 2014

\begin{abstract}
.
BACKGROUND: Human enhancement (the enhancement of the abilities of a normative person beyond the norm) of soldiers has been debated for some time. However, therapeutic enhancement of soldiers and veterans with injuries (the enhancement of the abilities of a sub-normative labeled person beyond the norm) is much less discussed.

OBJECTIVE: This article discusses 1) historical examples of policies and views linked to soldiers and veterans that have been injured in the Americas, and perception of injured veterans and soldiers; 2) the science and technology of the therapeutic enhancement landscape and 3) views of veterans on therapeutic enhancements.

METHODS: Three methods were used: a) historical search of policy documents; b) content analysis of the New York Times and c) online delivered exploratory non-probability survey using the Survey Monkey platform.

RESULTS: Researchers found that veterans played a special role in policy developments in the United States, such as disability pension plans, and that veterans who were injured were portrayed more positively than other people with disabilities in the NYT from 1851-2010. However, within the current public discourse around the use of enhancement enabling therapeutic assistive devices, the voices of injured soldiers and veterans are not visible.

CONCLUSIONS: Therapeutic enhancements, especially of injured soldiers and veterans, are an under researched area with various open ethical questions in need of more coverage.
\end{abstract}

Keywords: Human enhancements, veterans, soldiers, injured veterans, ethics

\section{Introduction}

So far, the very meaning of health, treatment and rehabilitation is benchmarked to the normal or speciestypical body. We expect certain abilities in members of

*Corresponding author: Gregor Wolbring, Department of Community Health Sciences, TRW Building, 3d31, 3330 Hospital Drive NWT2N4N1, Faculty of Medicine, University of Calgary, Calgary, Canada. E-mail: gwolbrin@ucalgary.ca; http://www.crds.org/ research/faculty/Gregor_Wolbring.shtml. a species; we expect humans to walk but not to fly, but a bird we expect to fly [1]. However, increasingly a) therapeutic interventions have the potential to give recipients beyond species-typical body related abilities (therapeutic enhancement) and b) so-called healthy people can obtain enhancers, whether they were used as therapeutics before or not, to gain non-therapeutic enhancement.

Human enhancement (the enhancement of the abilities of a normative person beyond the norm) of people outside of the therapeutic arena has been discussed 
for a long time [2-20] whereby many feel it should be legalized [21-34]. Much has also been written about the development and use of and push for human performance enhancement products for 'healthy' soldiers and their impact [3,35-49]. However, there are other areas of performance enhancement that are not adequately addressed in the literature, such as therapeutic enhancements (TE) (the enhancement of the abilities of sub-normative labeled people beyond the norm) [50]. TE is enabled by therapeutic assistive devices developed for restorative purposes that as a side effect increasingly allow the wearer to outperform the species-typical body in various functions. For example a brain-computer interface allows the wearer to control certain devices with their thoughts [51,52], which is something that humans are normally not capable of doing. TE increasingly becomes a therapeutic option for people with disabilities in general and for injured soldiers and veterans in particular [3]. The impact of TE in general and for injured veterans and soldiers in particular is however hardly discussed. Such silence might be a problem as a) discourses around TE will impact the discourses around so called non-TE and b) discourse around TE of soldiers and veterans that have been injured will be in particular impactful given that soldiers and veterans that have been injured were often at the forefront of paradigm shifting policy development (see Part 1a).

In this paper the following topics are discussed: 1) historical examples of policies and views linked to soldiers and veterans that have been injured in the Americas, and perception of veterans and soldiers that have been injured in the NYT; 2) the TE science and technology landscape and 3) views of members of one veterans group in Canada on a particular TE. This paper concludes that TE's especially of soldiers and veterans that have been injured is an under researched area with various open ethical, social and policy questions in need of more coverage.

\section{Part 1a: Historical policies regarding veterans with impairment in the Americas}

Injured veterans have often been at the forefront of policy developments. One example is the development of disability pension plans. Injured veterans had a disability pension scheme long before this type of pension system was set up for other veterans [53].

A 2007 report, A 21 st Century System for Evaluating Veterans for Disability Benefits written by the Commit- tee on Medical Evaluation of Veterans for Disability Compensation highlights many areas of innovations regarding the treatment of soldiers and veterans that have been injured.

In 1636, the Plymouth Colony enacted the first law in the English colonies in North America providing money to veterans who acquired disabilities because of battles with Pequot Indians [54].

"On August 26, 1776, the first pension legislation for the American colonies as a group was enacted. A resolution of the Continental Congress provided "half pay for life or during disability" was provided "to every officer, soldier, or sailor losing a limb in any engagement or being so disabled in the service of the United States as to render him incapable of earning a livelihood," and those partially disabled from getting a livelihood were promised proportionate relief (President's Commission, 1956b:5). The Revolutionary War Pension Act of 1818 (3 Stat. L., 410) moved the pension right beyond people who due to an impairment could not earn a living. "Veterans who had served at least nine months in the Continental Army and who were also "in reduced circumstances" received lifetime pensions at half-pay of the rank held during the Revolutionary War" [54].

Disability payments based on rank and degree of disability (meaning impairment) were provided by the General Pension Act of 1862 (12 Stat. L., 566) (the General Law), and it "applied to the Civil War and to any or all future wars in which the United Sates might be engaged" (President's Commission, 1956b:13) [54].

"The Economy Act of March 30, 1933 (P.L. No. 2, 73rd Cong.), which eliminated payments to all veterans without service-connected disabilities except those who were totally disabled and could meet an income test (President's Commission, 1956b:39), authorized the next version of the Rating Schedule" [54].

According to the Committee, the purpose of the 1945 rating system still used today "is to determine the extent to which impairment reduces earning capacity (work disability) the operational basis for these ratings is an evaluation of the severity of impairments resulting from the service connected injury or disease” [54].

The US Committee on Medical Evaluation of Veterans for Disability Compensation interpreted the compensation schemes for veterans in light of their inabil- 
ity to provide for themselves due to anatomical losses. The committee stated:

\begin{abstract}
"The original concern for the sacrifices made by those who serve our nation's colors had its genesis in the Revolutionary War, when loss of limbs, eyes, or other body parts sharply reduced a person's ability to support himself. This emphasis on anatomical loss persisted through the 19th century, was codified in the Rating Schedule developed to implement the War Risk Insurance Act of 1917, and retained with modifications in subsequent Rating Schedules, including the current one when it was developed in 1945" [54].
\end{abstract}

Interestingly the Committee on Medical Evaluation of Veterans for Disability Compensation reported in 2007 [54] that the way the U.S dealt with veterans and soldiers that were injured did not kept pace with the reality,

\begin{abstract}
"As the understanding of what constitutes disability has evolved, so has the ability to recognize and quantify the contributory components. The questions posed by the commission to this IOM committee reflect the uncertainties created by a lack of clear statement of purpose for the program, the use of an evaluation tool that has not kept pace with the changing dynamics of the likely losses incurred by our servicemen and servicewomen, and the changing economics of the workforce in America, as well as the changing social context into which our veterans return" [54].

"With members of the military being injured in combat nearly every day, the system of evaluating and rating disability should be as up to date as medical knowledge of impairment and its effects on a person's functioning and quality of life permits" [54].
\end{abstract}

Vietnam veterans that were injured are also seen as a main force behind the push for people with disabilities rights in the USA $[55,56]$ in the 1970's.

The question remains where the treatment and perception of as impaired evaluated veterans will go in the future.

\section{Part 1b: Historical perception of as impaired perceived veterans and non-veterans through the lens of the New York Times}

The NYT is by meaning of others [57] and its selfperception $[58,59]$ important in informing the 'aver- age' person on important issues. Therefore, it was decided to perform a thematic analysis of NYT articles (Table 1) covering perception of impaired veterans. We searched the New York Times archives systematically using (a) the ProQuest search engine (provided by the University of Calgary) for articles from 1851 to 2006 and (b) the archive search engine on the New York Times website for articles from 2006 to 2011 (August $16,2011)$ for the perception of veterans with impairment and compared it with perception of non-veteran people with impairments. Another inclusion criterion was that the articles had to cover employment as this is one of the most important issues in regards to people with disabilities, veterans or not. The analysis was limited to articles that had the terms in the title of an article as this indicates a higher focus on the given subject than if just mentioned in the body of the article. This search strategy led to manageable numbers of hits that could be investigated.

The themes present in the NYT articles in regards to people with impairments (Tables 2-4) were quite diverse. The most visible themes were: covering social and government aid, the types of jobs possible for people with impairment, that people with impairment have valuable abilities and that they have to be independent and help themselves. Statistics related to people with impairments were fairly invisible with for example employment statistics of people with impairments only mentioned once for blind people and once for deaf people. Various themes were only present related to veterans with impairments: "Need to improve care system", "We owe them", Housing/"national asylum." "reconstruction of disabled", persuading industry to hire, "human touch", "Aid for children of disabled", "Influencing public opinion" and "Not their fault."

To mention one specific theme, various articles cover public perception of people with disabilities. These articles had the theme of people with disabilities helping themselves [60-67] and these mention contribution to society $[62,65,68-72]$. We found positive and negative perceptions with the positive outperforming the negative 148 to 36 . Readers of the NYT received a diverse picture of people with disabilities although the reporting differed whether the topic was covering the blind, deaf, cripple (term used in the older issues of the newspaper), veterans that were injured or so called cognitively impaired people. Indeed certain positive themes such as "We owe them", "Not their fault", "Should get special treatment", "Positive impacts of disability" "Human Touch is needed", "Reconstruction of disabled" and "Heroics" were evident exclusively in 
Table 1

Keyword hits

\begin{tabular}{|c|c|c|c|c|c|}
\hline \multirow[t]{2}{*}{ Keywords } & \multicolumn{2}{|c|}{$1850-1950$} & \multicolumn{3}{|c|}{ Work in title keywords $1851-1950$} \\
\hline & Headline & Text & & Headline & Text \\
\hline & & & & 134543 & 1724881 \\
\hline Ability & 2,822 & 269,635 & ability & 165 & 6420 \\
\hline disab* & 4271 & 49049 & + disab* & 158 & 1428 \\
\hline Handicapped & 1302 & 22301 & Handicapped & 122 & 1096 \\
\hline Blind & 6474 & 97964 & Blind & 334 & 2218 \\
\hline Deaf & 1663 & 25556 & Deaf & 64 & 627 \\
\hline Lame & 690 & 88789 & Lame & 27 & 1468 \\
\hline Cripple* & 4633 & 43266 & Cripple* & 257 & 1646 \\
\hline Feeble & 473 & 22498 & Feeble & 23 & 736 \\
\hline Dumb & 534 & 13949 & Dumb & 22 & 442 \\
\hline Retard*/retarded & $571 / 1716$ & $13261 / 31598$ & Retard*/retarded & $148 / 60$ & $1059 / 431$ \\
\hline Mentally ill & 2 & 15 & Mentally ill & 2 & 15 \\
\hline Moron OR morons & 91 & 2834 & Moron & 4 & 89 \\
\hline Mentally defective & 0 & 41 & Mentally defective & 0 & 41 \\
\hline Learning disab* & 0 & 0 & Learning disab* & 0 & 0 \\
\hline Women & 111017 & 969734 & Women & 4189 & 22680 \\
\hline Indian & 27546 & 209020 & Indian & 585 & 4001 \\
\hline "the Poor" & 2615 & 74861 & "the Poor" & 227 & 3182 \\
\hline Negro & 20759 & 108067 & Negro & 540 & 2836 \\
\hline Veteran* & 31719 & 216707 & Veteran* & 847 & 4826 \\
\hline
\end{tabular}

Table 2

Themes prevalent in the NYT articles analyzed (1851-1950)

\begin{tabular}{|c|c|c|c|c|c|c|c|c|}
\hline \multirow{3}{*}{$\begin{array}{l}\text { Total } \\
\text { Type of disability } \\
\text { Social/government aid }\end{array}$} & \multirow{2}{*}{\multicolumn{2}{|c|}{$\begin{array}{c}96 \\
\text { Blind } \\
\text { (hits/\%) } \\
\end{array}$}} & \multirow{2}{*}{\multicolumn{2}{|c|}{$\begin{array}{c}95 \\
\text { Cripple } \\
\text { (hits/\%) }\end{array}$}} & \multirow{2}{*}{\multicolumn{2}{|c|}{$\begin{array}{c}64 \\
\begin{array}{c}\text { Deaf } \\
\text { (hits/\%) }\end{array}\end{array}$}} & \multirow{2}{*}{\multicolumn{2}{|c|}{$\begin{array}{c}286 \\
\text { 'Impaired' Veterans } \\
\text { (hits } / \% \text { ) }\end{array}$}} \\
\hline & & & & & & & & \\
\hline & 14 & 14.6 & 18 & 18.9 & 8 & 12.5 & 52 & 18.2 \\
\hline Valued abilities & 10 & 10.4 & 11 & 11.6 & 11 & 17.2 & 1 & 0.3 \\
\hline Types of Jobs & 18 & 18.8 & 8 & 8.4 & 5 & 7.8 & 57 & 19.9 \\
\hline Need for independence/help themselves & 13 & 13.5 & 13 & 13.7 & 6 & 9.4 & 18 & 6.3 \\
\hline Education & 5 & 5.2 & 6 & 6.3 & 7 & 10.9 & 3 & 1.0 \\
\hline Public perceptions of abilities & 9 & 9.4 & 2 & 2.1 & 5 & 7.8 & 0 & 0.0 \\
\hline Special abilities & 8 & 8.3 & 0 & 0.0 & 6 & 9.4 & 0 & 0.0 \\
\hline Contribution to society & 2 & 2.1 & 8 & 8.4 & 3 & 4.7 & 13 & 4.5 \\
\hline Statistics & 2 & 2.1 & 7 & 7.4 & 4 & 6.3 & 0 & 0.0 \\
\hline Policies and government & 4 & 4.2 & 4 & 4.2 & 2 & 3.1 & 30 & 10.5 \\
\hline Burden to society & 2 & 2.1 & 5 & 5.3 & 2 & 3.1 & 1 & 0.3 \\
\hline Gendered jobs & 4 & 4.2 & 2 & 2.1 & 1 & 1.6 & 13 & 4.5 \\
\hline Aid of technology & 0 & 0.0 & 3 & 3.2 & 1 & 1.6 & 5 & 1.7 \\
\hline Causes & 3 & 3.1 & 0 & 0.0 & 1 & 1.6 & 0 & 0.0 \\
\hline Discrimination & 0 & 0.0 & 2 & 2.1 & 1 & 1.6 & 7 & 2.4 \\
\hline Exploitation & 1 & 1.0 & 1 & 1.1 & 1 & 1.6 & 0 & 0.0 \\
\hline Negative terms & 1 & 1.0 & 2 & 2.1 & 0 & 0.0 & 0 & 0.0 \\
\hline Side-effects of unemployment & 0 & 0.0 & 3 & 3.2 & 0 & 0.0 & 0 & 0.0 \\
\hline Compensation & 0 & 0.0 & 0 & 0.0 & 0 & 0.0 & 22 & 7.7 \\
\hline Need to improve care system & 0 & 0.0 & 0 & 0.0 & 0 & 0.0 & 15 & 5.2 \\
\hline We owe them & 0 & 0.0 & 0 & 0.0 & 0 & 0.0 & 15 & 5.2 \\
\hline Housing/"national asylum" & 0 & 0.0 & 0 & 0.0 & 0 & 0.0 & 6 & 2.1 \\
\hline "reconstruction of disabled" & 0 & 0.0 & 0 & 0.0 & 0 & 0.0 & 6 & 2.1 \\
\hline Employment agencies & 0 & 0.0 & 0 & 0.0 & 0 & 0.0 & 6 & 2.1 \\
\hline Persuading industry to hire & 0 & 0.0 & 0 & 0.0 & 0 & 0.0 & 5 & 1.7 \\
\hline "human touch" & 0 & 0.0 & 0 & 0.0 & 0 & 0.0 & 4 & 1.4 \\
\hline Aid for children of disabled & 0 & 0.0 & 0 & 0.0 & 0 & 0.0 & 2 & 0.7 \\
\hline Influencing public opinion & 0 & 0.0 & 0 & 0.0 & 0 & 0.0 & 2 & 0.7 \\
\hline International efforts & 0 & 0.0 & 0 & 0.0 & 0 & 0.0 & 2 & 0.7 \\
\hline Not their fault & 0 & 0.0 & 0 & 0.0 & 0 & 0.0 & 1 & 0.3 \\
\hline
\end{tabular}


Table 3

Themes around public perception of NYT articles (1851-1950) analyzed

\begin{tabular}{|c|c|c|c|c|c|c|c|c|}
\hline \multirow[t]{2}{*}{ Total } & \multicolumn{2}{|c|}{36} & \multicolumn{2}{|c|}{31} & \multicolumn{2}{|c|}{18} & \multicolumn{2}{|c|}{80} \\
\hline & \multicolumn{2}{|c|}{$\begin{array}{c}\text { Blind } \\
\text { (hits/\%) }\end{array}$} & \multicolumn{2}{|c|}{$\begin{array}{l}\text { Cripple } \\
\text { (hits/\%) }\end{array}$} & \multicolumn{2}{|c|}{$\begin{array}{c}\begin{array}{c}\text { Deaf } \\
\text { (hits/\%) }\end{array} \\
\end{array}$} & \multicolumn{2}{|c|}{$\begin{array}{c}\text { 'Impaired' veterans } \\
\text { (hits/\%) }\end{array}$} \\
\hline \multicolumn{9}{|l|}{ Positive } \\
\hline Independence/Help themselves & 13 & 36.1 & 13 & 41.9 & 6 & 33.3 & 18 & 22.5 \\
\hline Need to contribute to society & 2 & 5.6 & 8 & 25.8 & 3 & 16.7 & 13 & 16.3 \\
\hline We owe them & 0 & 0.0 & 0 & 0.0 & 0 & 0.0 & 15 & 18.8 \\
\hline Not their fault & 0 & 0.0 & 0 & 0.0 & 0 & 0.0 & 1 & 1.3 \\
\hline Disability does not hinder ability & 5 & 13.9 & 1 & 3.2 & 3 & 16.7 & 0 & 0.0 \\
\hline Should get special treatment & 0 & 0.0 & 0 & 0.0 & 0 & 0.0 & 14 & 17.5 \\
\hline Positive impacts of disability & 0 & 0.0 & 0 & 0.0 & 0 & 0.0 & 1 & 1.3 \\
\hline "Human Touch" is needed & 0 & 0.0 & 0 & 0.0 & 0 & 0.0 & 4 & 5.0 \\
\hline "Reconstruction of disabled" & 0 & 0.0 & 0 & 0.0 & 0 & 0.0 & 6 & 7.5 \\
\hline Heroics & 0 & 0.0 & 0 & 0.0 & 0 & 0.0 & 3 & 3.8 \\
\hline \multicolumn{9}{|l|}{ Negative } \\
\hline Burden on society & 2 & 5.6 & 5 & 16.1 & 2 & 11.1 & 1 & 1.3 \\
\hline Negative imaging & 1 & 2.8 & 2 & 6.5 & 0 & 0.0 & 4 & 5.0 \\
\hline Jobs limited by disability & 7 & 19.4 & 1 & 3.2 & 3 & 16.7 & 0 & 0.0 \\
\hline Helplessness & 2 & 5.6 & 0 & 0.0 & 0 & 0.0 & 0 & 0.0 \\
\hline Need to prove themselves & 4 & 11.1 & 1 & 3.2 & 1 & 5.6 & 0 & 0.0 \\
\hline
\end{tabular}

the articles covering veterans that were injured. At the same time the negative images evident in the coverage of blind people, deaf people and cripples "Burden on society" "Jobs limited by disability", "Helplessness" "Need to prove themselves" were not present in the articles covering veterans that were injured.

\section{Part 2: Contemporary perception outside New York times}

The Committee on Medical Evaluation of Veterans for Disability Compensation concluded in 2007 [54] that the way the US dealt with soldiers and veterans that were injured did not keep pace with the reality. A 2011 Pew Research Centre Survey For many injured veterans, a lifetime of consequences [73] found that "one out of every ten veterans alive today was seriously injured" and "many of these 2.2 million wounded warriors, the physical and emotional consequences of their wounds have endured long after they left the military." Some of the other findings were "Veterans who suffered major service-related injuries are more than twice as likely as their more fortunate comrades to say they had difficulties readjusting to civilian life", "they are less likely in later life to be in overall good health or to hold full-time jobs", "Fully half $(52 \%)$ of all veterans badly injured while serving say the government has not given them, as a veteran, "all the help you think it should." Of soldiers wounded that served $67 \%$ believe that the government has NOT given them all the help they needed and $44 \%$ judged the care to be only fair or poor [73].

On the US Medicine.com webpage an article outlined the thesis that lifetime cost of treating the latest generation of veterans is higher than predicted [74]. Veterans that were injured are seen as a drain on health care [75] and society [76] because of their long term medical treatment needs. Alan Simpson, former Republican Senator from Wyoming, made it clear that he believes the health care benefits plan extended to American war veterans does little more than aggravate the US's fiscal trouble, at an estimated national cost of $\$ 42$ billion USD per year [75].

According to an article in Army Times "Tea party favorite Rep. Michele Bachmann, R-Minn, has unveiled a plan for cutting $\$ 400$ billion in federal spending that includes freezing Veterans Affairs Department health care spending and cutting veterans' disability benefits" [77].

Senator Tom Coburn, Republican of Oklahoma did hold up the Veterans' Caregiver and Omnibus Health Benefits Act of 2009, (S 1963) over concern about creating new and unfunded benefits [78]. On the other hand, it seems that society in general overlooks the fact that the health care benefits of veterans are extended to them because of the stresses of working in a combative environment. Psychologically one of the most common afflictions among veterans is PTSD (Post Traumatic Stress Disorder). Veterans living with PTSD are often highly stigmatized and even ostracized as a social group [79]. In general the coverage around Veterans 
Table 4

Themes around public perception NYT 1851-2011

\begin{tabular}{|c|c|c|c|c|c|}
\hline \multirow[b]{2}{*}{ Themes } & \multicolumn{2}{|c|}{$\begin{array}{c}\text { NYT 1851-1950 impaired } \\
\text { veterans } n=80 \\
\end{array}$} & \multicolumn{3}{|c|}{$\begin{array}{c}\text { NYT 1950-2011 impaired } \\
\text { veterans } n=196 \\
\end{array}$} \\
\hline & \# of Hits & $\%$ of Hits & $\begin{array}{c}\text { \# of Hits } \\
\text { mentioning theme }\end{array}$ & $\begin{array}{c}\text { \# of Doc. } \\
\text { (Total = } 196 \text { Doc.) }\end{array}$ & $\begin{array}{c}\% \text { Doc. mentioning } \\
\text { theme }\end{array}$ \\
\hline \multicolumn{6}{|l|}{ Positive } \\
\hline Independence/Help themselves & 18 & 22.5 & 8 & 4 & 2,04 \\
\hline Need to contribute to society & 13 & 16.3 & 1 & 1 & 0.51 \\
\hline We owe them & 15 & 18.8 & 15 & 12 & 6.12 \\
\hline Not their fault & 1 & 1.3 & 1 & 1 & 0.51 \\
\hline Disability does not hinder ability & 0 & 0.0 & 3 & 2 & 1.02 \\
\hline Should get special treatment & 14 & 17.5 & 47 & 31 & 15.8 \\
\hline Positive impacts of disability & 1 & 1.3 & 2 & 1 & 0.51 \\
\hline "Human Touch" is needed & 4 & 5.0 & 2 & 2 & 1.02 \\
\hline "Reconstruction of disabled" & 6 & 7.5 & 0 & 0 & 0 \\
\hline Heroics & 3 & 3.8 & 15 & 10 & 5.1 \\
\hline Job Creation & & & 30 & 21 & 10.7 \\
\hline Alternative Employment & & & 13 & 10 & 5.1 \\
\hline Tribute & & & 94 & 48 & 24.5 \\
\hline Gratitude & & & 35 & 17 & 8.67 \\
\hline Reintegration & & & 4 & 3 & 1.53 \\
\hline Compensation & & & 213 & 91 & 46.4 \\
\hline Accessibility & & & 41 & 14 & 7.14 \\
\hline Health Care Improvements & & & 2 & 2 & 1.02 \\
\hline Psycho-Social Support & & & 15 & 12 & 6.12 \\
\hline \multicolumn{6}{|l|}{ Negative } \\
\hline Burden on society & 1 & 1.3 & 8 & 6 & 3.06 \\
\hline Negative imaging & 4 & 5.0 & 23 & 12 & 6.12 \\
\hline Jobs limited by disability & 0 & 0.0 & 7 & 6 & 3.06 \\
\hline Helplessness & 0 & 0.0 & 3 & 3 & 1.53 \\
\hline Need to prove themselves & 0 & 0.0 & 0 & 0 & 0 \\
\hline Restrict Employment Opportunities & & & 19 & 18 & 9.18 \\
\hline Understanding of Veteran Needed & & & 14 & 11 & 5.61 \\
\hline Poor Health Care Access & & & 14 & 9 & 4.59 \\
\hline
\end{tabular}

that were injured in the public domain is quite inconsistent. Some say that veterans that were injured should use all rehab technologies possible/available [80-83]; should feel well taken care of [80]; deserve to be taken care of by the nation [84-89]. On the other hand veterans that were injured are stigmatized [88, 90-94]; are often unemployable [86,91]; aren't worth as much [93-95]; should be productive [92] and should integrate back into society well [96].

\section{Part 3: The Science \& Technology landscape}

Despite the perceived "drain" on the health care systems of North America [75], many rehabilitative interventions are being specifically designed for soldiers and veterans that have been injured [3] many of which could lead to TE. Due to the protection of soldiers, the fatality to impairment ratio changed in recent times dramatically with a decrease in fatality and increase in so called impairment. According to [97] important strides in providing vehicle and body armor, innova- tive changes in doctrine, tactics, techniques and procedures, and advances in military medical technology are having profound impacts on how many of our soldiers, sailors, airmen, Marines, and special operations warriors are surviving their wounds. "Since the war in Iraq began in 2003, Americans have suffered more than 3,000 Deaths and about 23,000 Casualties" [98]. According to the Defense Advanced Research Projects Agency (DARPA), more than 300 soldiers from the war in Iraq alone have returned home with major amputations [99]. DARPA has developed programs in conjunction with public and private medical research institutions looking at novel technologies allowing for soldier self-aid [100-104]. In 2004, an article outlined a soldier self-care vision [105]. "Future Soldiers may operate in encapsulated, climate-controlled, powered fighting suits, laced with sensors and boasting chameleon-like 'active' camouflage while 'skinpatch' pharmaceuticals help regulate fears, focus concentration and enhance endurance and strength" [104, 106]. These technologies are aimed at enabling the injured warfighter to address minor to moderate injuries 
without relying on outside support. This represents a paradigmatic shift from medic-centric to warfightercentric medical care [105]. Performance enhancing 'medication' is also on the radar screen of the military. The Navy has addressed "performance enhancement" medications [107], although some feel that this is not done extensively enough [104]. Various therapeutic programs exist that can move toward therapeutic enhancements such as DARPA's Cutting-Edge Programs Revolutionize Prosthetics [98,99,108,109]. The Telemedicine and Advanced Technology Research Center (TATRC) US Army Medical Research and Materiel Command has an advanced prosthetics and human performance program $[110,111]$ a medical sensor system [112-114] an exoskeleton for human performance augmentation program [115-118] and various regenerative medicine program [119-122].

\section{Part 4: Views of veterans on therapeutic enhancements}

What are the views of veterans? Will they resist or embrace TE? To answer these questions, non-injured members of a Canadian veteran group called Veteran Voice were asked the following question:

\section{"If you acquired an injury which led to the removal of your legs and you had the choice between a) ar- tificial legs that behave like a 'normal' leg there- fore do not outperform 'normal' legs; b) artificial legs that that are better than the 'normal' legs and c) no artificial legs but something like a wheelchair, which would you chose?"}

This question (q46) was the last one of a set of questions that were tailored to explore whether veterans' perceive the New Veterans' Charter (Canada) as sufficient to ensure a full continuum of client centered services and to gauge their perception regarding level of satisfaction with service provisions. An online delivered exploratory non-probability survey was administered using the Survey Monkey platform consisting of a combination of simple yes or no questions, a Likert scale, opinion self-rating scales, as well as open-ended questions. The preliminary draft survey was presented to five military affiliated organizations for feedback. The revised online survey was inputted into a previously activated Survey Monkey account, an online service provider that ensures that all data remains aggregate and encrypted for security purposes. The survey received ethics approval by University of Calgary
Health Research Ethics board. After ethics approval the survey links were activated and the link emailed to the group 'Veterans Voice forum' that had previously indicated that they would host the link creating an opportunity for data to be gathered via convenience sampling. As this is a non-probability sample no tests of significance were performed [123].

252 respondent responded to the survey of which $153(60.7 \%)$ filled out the complete survey. As to question 46 that is reported on in this paper, 28.1\% $(n=$ 43) of the veterans would prefer legs that do not outperform the 'normal' legs and $35.3 \%(n=54)$ legs that out performs 'normal' legs. Only $1.3 \%(n=2)$ would choose no artificial legs but something like a wheelchair and $35.3 \%(n=54)$ did not know what they would go for.

\section{Discussion}

Given the focus of science and technology on soldiers and veterans that were injured and the increasing feasibility of therapeutic enhancement of soldiers and veterans that were injured, the question arises: what is the discourse so far around this topic? In short, the answer is very little to none which is a problem. Data presented in Part 1 highlights the impact veterans that were injured had on policies that in the end impacted society. Data presented in Part $1 \mathrm{~b}$ showed that veterans that were injured are covered differently in the New York Times than other people with disabilities and different sentiments are linked to them than nonmilitary related people with disabilities. Part 2 shows that the contemporary view of veterans that were injured is more ambivalent. For many, veterans injured or not are a social group to be honored and revered, a group that members of society owe their gratitude to for serving to protect the citizens of their country, keeping the peace, or otherwise. Thus, this group sees it as appropriate that members of society pay them their respects by extending benefits exclusive to them, including but not limited to health care and educational benefits. However data presented in Part 2 also shows that there are others, who see veterans injured or not in a much dimmer and less glamorous light. Veterans often feel stigmatized for various reasons and veterans and soldiers that were injured especially in the post 9/11 era feel they do not receive the help they need and that they have a high problem with integration into society [73]. Both groups of sentiments influence the behavior of veterans that were injured. The question 
remains whether the negative perception veterans and soldiers that were injured have of their living situation makes them more open to using enhancement technologies.

In 2002, Donovan, Egger, Kapernick and Mendoza investigated what might generate a climate of achieving Performance Enhancing Drug Compliance in Sport [124] meaning that these drugs are not taken. They postulated that six major inputs that shape the behavior of an athlete are a) threat appraisal; b) benefit appraisal; c) reference group influences; d) personal morality; e) legitimacy and f) personality factors [124].

Soldiers and veterans that were injured experience above average unemployment rate and stigmatization. They feel that they do not receive the care they deserve and they experience problems with integrating back into society. Given this, it seems obvious that veterans if injured would not only choose to regain their normal functioning (artificial leg preference over wheelchair) but if available would choose enhancement enabling therapeutic devices (artificial legs with beyond the normal abilities) [125]. The choice of enhancement enabling therapeutic devices over non enhancement enabling devices one can predict will be seen as highly beneficial and not immoral. They will have a high support level in the relevant support groups and laws and regulations will be seen as having no legitimacy to prevent these kinds of enhancements. Indeed results of two recently performed exploratory studies (one covering members of the World Federation of the Deaf and the other covering members of the National Council of Rehabilitation Educators) reveal very little resistance toward therapeutic enhancement $[125,126]$. Furthermore the former general secretary of the World Transhumanist Association, a group that pushes for the enhancement beyond the normal in general, believes that people with disabilities, in general, are trailblazers for enhancements as they are seen to embrace these enhancements readily [127].

Indeed given today's reality of soldiers and veterans that were injured, obtaining enhancement enabling therapeutic devices not only would make living in the community easier but might allow them to return back to their life as soldiers and even back to active duty [128-130]. The narrative around and purpose of obtaining prosthetic limbs by soldiers and veterans that were injured seems to change by adding to the therapeutic aspects as the desirable endpoint a narrative and desire to enhance the wearer's abilities beyond what a human being is naturally capable of on the battlefield. These types of assistive devices might be the best chance for a soldier that was injured to be allowed back into active duty as these 'fixed' soldiers would have a combative advantage which would make it more likely that the 'fixed' soldier will be allowed to go back to a life they have known before. Starting with World War II and continuing on through history to Vietnam, Korea, the Gulf and more contemporarily Iraq and Afghanistan wars, veterans have been made to feel liberated by being enabled to become active again, through competing in sport and more specifically the Paralympics [131,132]. Of competition, Kortney Clemons said "Being competitive is a good thing because you can do it the rest of your life. We even compete with ourselves" [133]. In the belief of veterans to be highly competitive above the normal standard [134], also recognized by Guttmann: the will to win is always strongest amongst "the paralyzed" during national and international contests (Guttmann $1976,33)$, veterans continue to be considered as tactical athletes [134].

This changing narrative has various ethical angles that are not really explored yet. One being that all kinds of injuries are inflicted onto soldiers, some physical and some mental; for some there might be assistive bodily devices to go back to active duty, but for others there are not. It seems a two tiered system of injuries with different reintegration potential is appearing.

The trickle down of therapeutic enhancements to non-soldiers and veterans that were not injured is another ethical issue and an area not much debated as of yet. Lin in his piece about Robotics, Ethics and war [135] addresses consequences stemming from the fact that every enhanced soldier "is a potential veteran, returning to society from their military Service" [135]. He highlights that "approximately 23 million veterans today live in the US, accounting for about one in 10 adults, plus three million active and reserve military personnel" [135]. However the consequences are just as real for the 2.2 million veterans that were injured [73] existing today. Even more, as many of these therapeutic enhancements can also be performed on non-veterans that were injured the impact will increase by 10 fold given the numbers of disabled people in the US. People with disabilities [126], rehabilitation educators [125] and others [127] expect that many of these enhancement enabling therapeutic devices will also be sought out by so-called healthy people.

Lin concluded that various questions must be asked in regards to enhancing soldiers, such as whether these effects have to be reversed upon moving back to civilian life and if not reversible whether they should be 
allowed to return to civil life; what might be the social disruption of the return of the enhanced soldier into civilian life onto the non-enhanced and how do we evaluate issues of access, fairness and equity [135]?

Similar questions can be asked around therapeutically enhanced veterans that were injured. In sport these kinds of questions are asked already as the time seems to be near where a bionic leg outperforms the normal leg which raises all kinds of issues of expectation of disabled athletes and their relationship to nonimpaired labeled athletes [136] and expectations of sponsors, governments and spectators [137].

However, a public discourse around the impact of the availability of enhancement enabling therapeutic assistive devices for soldiers and veterans that were injured does not exist, nor does a discourse exist around the role of the technology developers, the rehabilitation professionals, the veteran and soldier that was injured, officials from veteran affairs, politicians involved in the discourse around the health care of veterans and soldiers that were injured, and academics involved in enhancement and healthcare policy. Furthermore, no discourse exists among people with disabilities and their organizations as to the impact of enhancement enabling therapeutic assistive devices. Many unexplored areas related to veterans and soldiers that were injured and therapeutic enhancements are in need of exploration.

\section{References}

[1] Wolbring G, Diep L, Yumakulov S, Ball N, Leopatra V, Yergens D. Emerging Therapeutic Enhancement Enabling Health Technologies and Their Discourses: What Is Discussed within the Health Domain? Healthcare. 2013; 1(1): 20-52. PubMed PMID: doi:10.3390/healthcare1010020.

[2] Lewens T. The risks of progress: Precaution and the case of human enhancement. Journal of Risk Research. 2010; 13(2): 207-16.

[3] Coenen C, Schuijff M, Smits M, Klaassen P, Hennen L, Rader M, et al. Human Enhancement Study. 2009 2009. Report No.: (IP/A/STOA/FWC/2005-28/SC35, 41 \& 45) PE 417.483.

[4] Gunson D. Cognitive Enhancement, Analogical Reasoning and Social Justice. Journal of International Biotechnology Law. 2009; 6(1): 133-49.

[5] Buchanan A. Moral Status and Human Enhancement. Philosophy \& Public Affairs. 2009; 37(4): 346-81.

[6] Pound RW. Human enhancement. Issues in Science and Technology. 2009; 25(4): 5-.

[7] Riis J, Simmons JP, Goodwin GP. Preferences for Enhancement Pharmaceuticals: The Reluctance to Enhance Fundamental Traits. Journal of Consumer Research. 2008; 35(10): 495-508.

[8] Beck S. Enhancement as a Legal Challenge. Journal of International Biotechnology Law. 2007; 4(2): 75-81.
[9] Irish Council for Bioethics. Human Enhancement: Making People Better or Making Better People? Irish Council for Bioethics [Internet]. 2007. Available from: http://www. bioethics.ie/uploads/docs/Humanenh.pdf.

[10] Tomasini F. Imagining human enhancement: whose future, which rationality? Theoretical Medicine and Bioethics. 12/2007; 28(6): 497-507.

[11] Williams AE. Good, Better, Best: The Human Quest for Enhancement Summary Report of an Invitational Workshop Convened by the Scientific Freedom, Responsibility and Law Program American Association for the Advancement of Science June 1-2, 2006. AmericanAssociation for the Advancement of Science (AAAS) [Internet]. Available from: http://www.aaas.org/spp/sfrl/projects/human_enhancement/ pdfs/HESummaryReport.pdf.

[12] Robert JS. Human dispossession and human enhancement. AmJ Bioeth. 2005 2005; 5(3): 27-9.

[13] Rothman S RD. The pursuit of perfection: The promise and perils of medical enhancement: New York: Pantheon Books, 2005.

[14] Baylis F, Robert JS. The inevitability of genetic enhancement technologies. Bioethics. 2004; 18(1): 1-26.

[15] Caplan A EC. Is It Ethical to Use Enhancement Technologies to Make Us Better than Well? PLOS Med. 2004; 1(3): 52

[16] Farah M, Illes J, Cook-Deegan R, Gardner H, Kandel E, King P, et al. Neurocognitive enhancement: What can we do and what should we do? Nat Rev Neurosci. 2004; 5: 421-5.

[17] Khushf G. Systems theory and the ethics of human enhancement - A framework for NBIC convergence. Coevolution of Human Potential and Converging Technologies. 2004; 1013: 124-49.

[18] Russo E. For Fear of a 'Cognitive Divide' Developing safe, specific, powerful memory-improving drugs raises many ethical issues about the implications of cognitive enhancement. The Scientist. 2002 October 28; 16(21): 29.

[19] Brodey WM, Lindgren N. Human Enhancement - Beyond Machine Age. Ieee Spectrum. 1968; 5(2): 79-\&.

[20] President's Council on Bioethics. Beyond therapy: Biotechnology and the pursuit of happiness. 2003. Report No.

[21] Miah A. Towards the transhuman athlete: therapy, nontherapy and enhancement. Sport in Society: Cultures, Commerce, Media, Politics. 2010; 13(2): 221-33.

[22] Bostrom N, Sandberg A. Cognitive Enhancement: Methods, Ethics, Regulatory Challenges. Science and Engineering Ethics. 9/2009; 15(3): 311-41.

[23] Bostrom N, Roache R. Ethical Issues in Human Enhancement. In: Ryberg J, editor. New Waves in Applied Ethics: Palgrave Macmillan, 2007.

[24] UK House of Commons Science and Technology Committee. Human Enhancement Technologies in Sport. 2007. Report No.

[25] Hughes J. Human Enhancement and the Emergent Technopolitics of the 21st Century. In: MC R, Bainsbridge W, editors. Managing Nano-Bio-Info-Cogno Innovations: Converging Technologies in Society. New York: Springer, 2006.

[26] Savulescu J. Justice, fairness, and enhancement. Progress in Convergence: Technologies for Human Wellbeing. 2006; 1093: 321-38

[27] Miah A. Rethinking enhancement in sport. Progress in Convergence: Technologies for Human Wellbeing. 2006; 1093: 301-20.

[28] Bostrom N. In defense of posthuman dignity. Bioethics. 6/2005; 19(3): 202-14. 
[29] Bostrom N. Human Genetic Enhancements: A Transhumanist Perspective. Journal of Value Inquiry. 2005, p. 493-506.

[30] Savulescu J. New breeds of humans: The moral obligation to enhance. ReprodBiomedOnline. 3/2005; 10 Suppl 1: 36-9.

[31] Caplan AL. Straining their brains: Why the case against enhancement is not persuasive. Cerebrum. 2004; 6(4): 14-8.

[32] Caplan AL. Is better best? A noted ethicist argues in favor of brain enhancement. Sci Am. 9/2003; 289(3): 104-5.

[33] Harris J. Enhancing Evolution The Ethical Case for Making Better People: Princeton University Press, 2007.

[34] Wolbring G. Ethical Theories and Discourses through an Ability Expectations and Ableism Lens: The Case of Enhancement and Global Regulation. Asian Bioethics Review. 2012; 4(4): 293-309.

[35] Masters C. Bodies of Technology: Cyborg Soldiers and Militarized Masculinity. Paper presented at the annual meeting of the International Studies Association, Town \& Country Resort and Convention Center, San Diego, California, USA [Internet]. 2008. Available from: http://www.allacademic.com/ meta/p_mla_apa_research_citation/1/0/0/2/8/p100286_ index.html.

[36] Sierra. Brain Chips for Future Soldiers. Techpincom [Internet]. 2007. Available from: http://www.techpin.com/brainchips-for-future-soldiers/.

[37] Staticbrain.com. Brain Machine Interface: BMI (Cyborg Soldiers). sTATICBRAINCOM [Internet]. 2008. Available from: http://www.staticbrain.com/archive/brain-machineinterface-bmi-cyborg-soldiers/.

[38] Weinberger S. Could Soldiers Be Prosecuted for Thought Crime? Wired Magazine Blog, The Danger Room [Internet]. 2008. Available from: http://blog.wired.com/defense/ 2008/04/can-soldiers-be.html.

[39] South African Times. Cyborg soldiers learn hi-tech killing. South African Times [Internet]. 2000. Available from: http: //www.iol.co.za/index.php?set_id=1\&click_id=31\&art_id= qw96588126072B251.

[40] english.chosum.com. Cyborg' Soldiers to Be Kitted Out by 2020. english chosumcom [Internet]. 2007. Available from: http://english.chosun.com/w21data/html/news/200705/2007 05230023.html.

[41] Shachtman N. DARPA Wants Soldiers to Touch, From 300 Feet Away. Wired Magazine Blog, The Danger Room [Internet]. 2008. Available from: http://blog.wired.com/defense/ 2008/04/darpa-wants-sol.html.

[42] Henry A. Nanotechnology Makes Way for Cyborg Soldiers. Boston Underground [Internet]. 2006. Available from: http:// www.bostonunderground.info/article.php?id=70\&issue $=47$.

[43] Thomas A. Pentagon to implant microchips in soldiers' brains. PressESC [Internet]. 2007. Available from: http:// pressesc.com/news/80530072007/pentagon-implantmicrochips-soldiers-brains.

[44] Spears T. New drug may help soldiers stay awake Doctors unsure of long-term effect. The Ottawa Citizen. 2003 October 11 .

[45] Weinberger S. Pentagon to Merge Next-Gen Binoculars With Soldiers' Brains. Wired Magazine [Internet]. 2007. Available from: http://www.wired.com/gadgets/miscellane ous/news/2007/05/binoculars.

[46] Aftermath News. Should We Make Cyborg Soldiers? Aftermath News [Internet]. 2006. Available from: http://after mathnews.wordpress.com/2006/09/29/should-we-makecyborg-soldiers/.

[47] Cyberpunk. Soldiers as Cyborgs. Cyberpunkreview [Internet]. 2006. Available from: http://www.cyberpunkreview. com/news-as-cyberpunk/soldiers-as-cyborgs/.

[48] Smart J. Human Performance Enhancement in 2032: A Scenario for Military Planners, Accelertation Studies Foundation [Internet]. 2011. Available from: http://accelerating.org/ articles/hpe2032army.html.

[49] O'Meara RM. Emerging military technologies in the 21st Century, 2011.

[50] Wolbring G. HTA Initiative \#23 The triangle of enhancement medicine, disabled people, and the concept of health: A new challenge for HTA, health research, and health policy. Alberta Heritage Foundation for Medical Research (AHFMR) webpage: Alberta Heritage Foundation for Medical Research (AHFMR), 2005. Report No.

[51] Diep L, Wolbring G. Who Needs to Fit in? Who Gets to Stand out? Communication Technologies Including BrainMachine Interfaces Revealed from the Perspectives of Special Education School Teachers Through an Ableism Lens. Education Sciences. 2013; 3(1): 30-49. PubMed PMID: doi:10.3390/educsci3010030.

[52] Wolbring G, Diep L, Yumakulov S, Ball N, Yergens D. Social Robots, Brain Machine Interfaces and Neuro/Cognitive Enhancers: Three Emerging Science and Technology Products through the Lens of Technology Acceptance Theories, Models and Frameworks. Technologies. 2013; 1(1): 3-25. PubMed PMID: doi:10.3390/technologies 1010003.

[53] Department of Veteran Affairs U. VA History in Brief 2014. Available from: http://www.va.gov/opa/publications/ archives/docs/history_in_brief.pdf.

[54] Committee on Medical Evaluation of Veterans for Disability Compensation. A 21st Century System for Evaluating Veterans for Disability Benefits. Washington, DC: National Academy Press, 2007.

[55] Shapiro JP. No pity: People with disabilities forging a new civil rights movement: Three Rivers Press, 1994.

[56] Sullivan M. A Unique Lens to Explore an Emerging Field. UCLA College report [Internet]. 2007. Available from: http://www.disabilitystudies.ucla.edu/docs/EmergingField.pdf

[57] New York Times. The Civitas reception. New York Times. $5 / 2 / 1895$.

[58] Nord DP. A Republican Literature: A Study of Magazine Reading and Readers in Late Eighteenth-Century New York. American Quarterly. 1988; 40(1): 42-64.

[59] New York Times Magazine. On the Means of Preserving Public Liberty. N Y Times Mag, 1790.

[60] Washington Post. Work of a blind women. Washington Post. 9/2/1902.

[61] Washington Post. The blind at work. Washington Post. 4/3/1902.

[62] New York Times. Blind and lame soldier at work. New York Times. 12/23/1917.

[63] S.B.T. Aiding the blind. New York Times. 12/18/1912.

[64] New York Times. Cripples now share public school works. New York Times. 3/21/1909.

[65] New York Times. Seek occupations for war cripples. New York Times. 9/4/1917.

[66] New York Times. Tunney applauds cripples as heroes. New York Times. 5/10/1928.

[67] New York Times. Woman Trains Cripples to Earn Own Living; Vermont Advances Cost of Handicraft. New York Times. 11/7/1937.

[68] New York Times. Floating hotel gives work to cripples. New York Times. 1/13/1908. 
[69] New York Times. Work they can do taught to cripples. New York Times. 10/18/1914.

[70] New York Times. Places 111 cripples. New York Times. 6/27/1918.

[71] New York Times. Work for war cripples. New York Times. $5 / 3 / 1918$

[72] New York Times. Disabled aid work held inadequate. New York Times. 11/5/1947.

[73] Pew Research Center. For many injured veterans, a lifetime of consequences. Pew Research Center [Internet]. 2011. Available from: http://www.pewsocialtrends.org/files/ 2011/11/Wounded-Warriors.pdf.

[74] U.S. Medicine.com. Lifetime Cost of Treating Latest Generation of Veterans Higher than Predicted. USMedicinecom [Internet]. 2010. Available from: http://www.usmedicine. com/physicalmedicine/lifetime-cost-of-treating-latestgeneration-of-veterans-higher-than-predicted.html.

[75] Guilluton S. Alan Simpson calls veterans health benefits a drain on the U.S. economy. Examinercom [Internet]. 2010. Available from: http://www.examiner.com/health-care-in-na tional/alan-simpson-calls-veterans-health-benefits-a-drainon-the-u-s-economy.

[76] Daly R. APA Urges Congress to Extend Types, Length of Care for All Vets. Psychiatric News. 2007; 42(12): 4.

[77] Maze R. Bachmann plan would cut veterans benefits. Army Times [Internet]. 2011. Available from: http://www. armytimes.com/news/2011/01/military-michele-bachmannveterans-budget-cuts- $012811 \mathrm{w} /$.

[78] Maze R. Coburn named as senator holding up vets bill. Army Times [Internet]. 2009. Available from: http://www.army times.com/news/2009/11/military_veteransbill_coburnhold _110309w/.

[79] Madison L. Obama: PTSD stigmatization must end. CBS News [Internet]. 2011. Available from: http://www.cbsnews. com/8301-503544_162-20099337-503544.html.

[80] Downs Jr F. Veterans Care:Ensuring Top Prosthetic Care is P.S.A. Goal. inMotion A Publication of the Amputee Coalition [Internet]. 1995. Available from: http://www.amputeecoalition.org/inmotion/spring_95/veterans.html.

[81] PBS.org. The obstacle in getting help. PBSorg [Internet]. 2005. Available from: http://www.pbs.org/wgbh/pages/ frontline/shows/heart/themes/stigma.html.

[82] Sam S. How America Can Be Loved by Everyone. Sam Snyder blog [Internet]. 2011. Available from: http://samsnyder. com/2011/05/13/how-america-can-be-loved-by-everyone/.

[83] Shane III L. X2 prosthetic leg now offered to older veterans. Stars and Stripes [Internet]. 2010. Available from: http:// www.stripes.com/news/x2-prosthetic-leg-now-offered-toolder-veterans-1.115257.

[84] Newman J. Vet vents on stigma attached to diagnoses. 2011.

[85] Health estate facilities management Association (HefmA). Veteran Health Outcomes to be Improved. Health estate facilities management Association (HefmA) [Internet]. 2010. Available from: http://www.hefma.org.uk/news/item/veteran -health-outcomes-to-be-improved.

[86] National Veterans Foundation. A Great New Service for Veteran Amputees. National Veterans Federation [Internet]. 2010. Available from: http://www.nvf.org/blog/item/57.

[87] The O\&P Edge. UK Looks to Improve Prosthetic Services for Veterans. oandpcom [Internet]. 2011. Available from: http://www.oandp.com/articles/NEWS_2011-01-06_01.asp.

[88] New Jersey Governor's Council on Mental Health Stigma. Campaign helps veterans battle mental health stigma. State of New Jersey, USA [Internet]. 2008. Available from: http:// www.state.nj.us/mhstigmacouncil/home/news/council/ approved/081014.html.

[89] Altmire Jason Congressman. Altmire Amednment AdoptedWill Improve Veteran's Access to Quality Prosthetics. Congressman Jason Altmire webpage [Internet]. 2011. Available from: http://altmire.house.gov/index.php?option=com_con tent $\&$ view=article \&id=763:altmire-amendment-adoptedwill-improve-veterans-access-to-quality-prosthetics\&catid= 21.

[90] Americans Who Support PTSD Veterans. What is the stigma of PTSD? Americans Who Support PTSD Veterans [Internet]. 2011 9/18/2011. Available from: http://www.capveter ans.com/americans_who_support_ptsd_veterans/id45.html.

[91] Boerstler J. Employing veterans: why is it so difficult? Part 3.

[92] National Council for Community Behavioral Healthcare. Helping Veterans Overcome Mental Illness Stigma. National Council for Community Behavioral Healthcare [Internet]. 2011. Available from: http://www.thenationalcouncil.org/cs/ helping_veterans_overcome_mental_illness_stigma.

[93] U.S.Medicine. Servicemembers and Veterans Use Programs to Help Each Other Overcome Stigma. USMedicinecom [Internet]. 2010. Available from: http://www.usmedicine.com/ articles/servicemembers-and-veterans-use-programs-to-help -each-other-overcome-stigma.html.

[94] Capps R. Reducing Stigma of PTSD in Army Culture. 2010.

[95] Duggan B. Fighting the Stigma: Time to Appreciate our Veterans. 2010.

[96] Frueh C. PTSD: the pitfalls of stigma and stereotypes. 2010.

[97] Galdorisi G, V, Truver S, C. The Golden Hour for Wounded Warriors. Military Medical Technology Online. 2008; 12(3).

[98] Caron SR. Battlefield Advances. Caron's webpage [Internet]. 2008. Available from: http://keepourcountryfree.tripod. com/id27.html.

[99] Applied Physics Laboratory JHU. Armed with Ideas - APL Leads Prosthesis Development Team. Applied Physics Laboratory, John Hopkins University [Internet]. 2006. Available from: http://www.jhuapl.edu/newscenter/aplnews/2006/ prostheticarm.asp.

[100] Center NMR. Hematomimetics Program. Naval Medical Research Center [Internet]. 2008. Available from: http://www. nmrc.navy.mil/hp.htm.

[101] Claburn T. DARPA Wants 'Fracture Putty' To Fix Broken Bones. Informationweek [Internet]. 2008. Available from: http://www.informationweek.com/news/management/smb/ showArticle.jhtml?articleID=208402631.

[102] Mechanics.com P. Deep Bleeder Acoustic Coagulation (DBAC). Popular Mechanicscom [Internet]. 2007. Available from: http://www.popularmechanics.com/science/health_ medicine/4220228.html?page $=3$.

[103] Mechanics.com P. Simplified Automated Ventilator (SAVe). Popular Mechanicscom [Internet]. 2007. Available from: http://www.popularmechanics.com/science/health_medicine /4220228.html?page=5, http://www.automedx.biz/.

[104] Farrell M. DARPA, PNAC and the Perfect Killing Machine. BuzzFlashcom [Internet]. 2003. Available from: http://www. buzzflash.com/farrell/03/06/24.html.

[105] Whelan H, T, Hale-Richlen B, L, Pharaon M, R, Henry K, A. Soldier Self Care. Military Medical Technology Online. 2004; 8(3).

[106] Century PftNA. Rebuilding America's Defenses Strategy, Forces and Resources For a New Century. 2000. Report No.

[107] NAVY. Performance Maintenance During Continuous Flight 
Operations A Guide for Flight Surgeons. NAVAL Strike and Air Warfare Center: 2000. Report No.: NAVMED P-6410.

[108] Miles D. DARPA's Cutting-Edge Programs Revolutionize Prosthetics. American Forces Press Service [Internet]. 2006. Available from: http://www.defenselink.mil/news/newsarti cle.aspx?id=14914.

[109] Popular Mechanics.com. Revolutionizing Prosthetics (RP). Popular Mechanicscom [Internet]. 2007. Available from: http://www.popularmechanics.com/science/health_medicine /4220228.html?page $=4$.

[110] Telemedicine and Advanced Technology Research Center (TATRC) U.S.Army Medical Research and Materiel Command. Advanced prosthetics and human performance. Telemedicine and Advanced Technology Research Center (TATRC) USArmy Medical Research and Materiel Command [Internet]. 2008. Available from: http://www.tatrc.org/ portfolios.html\#advanced_prosthetics.

[111] Strategic Technology Office USA. Sensor Tape Program. Strategic Technology Office,USA [Internet]. 2008. Available from: http://www.darpa.mil/STO/Solicitations/sensortape/ index.html.

[112] Weinberger S. Speed Gauge for Soldiers' Heads. Danger Room, Wired Blog [Internet]. 2007. Available from: http:// blog.wired.com/defense/2007/06/they_army_wants.html.

[113] Zenhausern F, Jabbour G. ASU researchers demonstrate wearable electronics to aid health and fashion at wired magazine's NextFest. Arizona State University, 2004.

[114] Science Daily. Smart Clothes: Textiles That Track Your Health. Science Daily webpage [Internet]. 2008. Available from: http://www.sciencedaily.com/releases/2008/03/08032 9121141.htm.

[115] Gizmag. Exoskeletons: Wearable Robots. gizmag [Internet]. 2008. Available from: http://www.gizmag.com/go/1604/.

[116] Raytheon. The Exoskeleton: Advanced Robotics. Raytheon [Internet]. 2011. Available from: http://www.raytheon.com/ newsroom/technology/rtn08_exoskeleton/.

[117] Emmer G. Exoskeleton. exoskeleton-suitcom [Internet]. 2011. Available from: http://www.exoskeleton-suit.com/.

[118] Strickland E. Good-bye, wheelchair. IEEE Spectrum. 2012; 49(1): 30-2

[119] McGowan Institute for Regenerative Medicine. DARPA Supports Research Toward Realizing Tissue Regeneration. McGowan Institute for Regenerative Medicine [Internet]. 2008. Available from: http://www.mirm.pitt.edu/news/arti cle.asp?qEmpID=133.

[120] Telemedicine and Advanced Technology Research Center (TATRC) U.S.Army Medical Research and Materiel Command. Regenerative Medicine. Telemedicine and Advanced Technology Research Center (TATRC) USArmy Medical Research and Materiel Command [Internet]. 2008. Available from: http://www.tatrc.org/portfolios.html\#regenerative _medicine.

[121] Naval Medical Research Center USA. Regenerative Medicine. Naval Medical Research Center USA [Internet]. 2008. Available from: http://www.nmrc.navy.mil/nmrc_ccc_ rci.htm.

[122] Axe D. Army Aims for New Six Million Dollar Man. Wired
Magazine Blog [Internet]. 2008. Available from: http://blog. wired.com/defense/2008/05/gentlemen-we-ca.html.

123] The Advisory Panel on Online Public Opinion Survey Quality. Standards and Guidelines for Sampling. Public Works and Government Services Canada [Internet]. 2011. Available from: http://www.tpsgc-pwgsc.gc.ca/rop-por/rapports-repor ts/comiteenligne-panelonline/page-03-eng.html, http://www.tpsgc-pwgsc.gc.ca/rop-por/rapports-reports/com iteenligne-panelonline/page-03-eng.html. Accessed: 201104-05. (Archived by WebCite?at http://www.webcitation.org 15xieLP2yT).

[124] Donovan RJ, Egger G, Kapernick V, Mendoza J. A Conceptual Framework for Achieving Performance Enhancing Drug Compliance in Sport. Sports Medicine. 2002; 32(4): 269-84.

[125] Wolbring G. Therapeutic Enhancements and the view of Rehabilitation Educators. Dilemata International Journal of Applied Ethics. 2012(8): 169-83.

[126] Wolbring G. Hearing Beyond the Normal Enabled by Therapeutic Devices: The Role of the Recipient and the Hearing Profession. Neuroethics. 6/1/2011; 6(3): 607-16.

[127] Hughes J. Battle Plan to Be More than Well Transhumanism is finally getting in gear. World Transhumanist Association Webpage [Internet]. 2004. Available from: http://transhu manism.org/index.php/th/more/509/.

[128] Bernton H. Medal recipient's prosthetic helps him return to unit. Seattle Times [Internet]. 2011. Available from: http:// seattletimes.nwsource.com/html/localnews/2015663637_ medalhonor $20 \mathrm{~m} . \mathrm{html}$

[129] Martin P. Return to Combat. O\&P Edge [Internet]. 2011. Available from: http://www.oandp.com/articles/201101_01.asp.

[130] Pitman T. Double-Amputee Soldier Returns To Duty ... And Is Fighting On The Front Lines In Afghanistan. Aol News [Internet]. 2010. Available from: http://www.aolnews. com/2010/09/25/wounded-in-iraq-double-amputee-returnsto-war/.

[131] Ability Magazine. Paralympic Military Program2011. Available from: http://www.abilitymagazine.com/Paralympic_ Military.html

[132] Batts C, Andrews DL. Tactical athletes: the United States Paralympic Military Program and the mobilization of the disabled soldier/athlete. Sport in Society. 2011; 14(5): 55368.

[133] Zinser L. Encouraged to compete. New York Times. 2005.

[134] Zinser L. Competition offers its healing powers to war's wounded New York Times 2005.

[135] Lin P. Robots, Ethics and war. Stanford Law School [Internet]. 2010. Available from: http://cyberlaw.stanford.edu/ node/6571.

[136] Wolbring G. Therapeutic bodily assistive devices and paralympic athlete expectations in winter sport. Clinical Journal of Sport Medicine. 2012; 22(1): 51-7.

[137] Wolbring G. One World, One Olympics: Governing Human Ability, Ableism and Disablism in an Era of Bodily Enhancements. In: Miah A, editor. Human Futures: Art in the Age of Uncertainty. Liverpool: Liverpool University Press, 2008 